Volume 2 No. 2, Desember 2017

P ISSN 2442-594X | E ISSN 2579-5708

http://journal.iainlangsa.ac.id/index.php/tibyan

\title{
TAFSIR ALQURAN TENTANG AKAL (Sebuah Tinjauan Tematis)
}

The Interest Of Qur'an About The Acts (A Thematic's Review)

\author{
Arifin Zein \\ Universitas Islam Negeri Ar-Raniry Banda Aceh \\ zainarifin.zain68@gmail.com
}

\begin{abstract}
This article discusses reason in the concept of the Koran. 'Aql in the Qur'an repeats as many as 49 times, except for one, all come in the form of fi'il mudhari', especially the material that continues with wawu jama'ah. Like the form of ta'qilun or ya'qilun. The verb ta'qilun is repeated 24 times and the verb ya'qilun is 22 times. Whereas, the verbs' aqala, na'qilu, and ya'qilu each have one time. From a number of verses of the Qur'an it can be understood that, reason has several meanings, including the power to understand and describe something, moral drive and power to take lessons and conclusions and wisdom
\end{abstract}

Keywords: 'Aqal, 'aqala, ta'qilun

\begin{abstract}
Abstrak
Artikel ini membahas tentang akal dalam konsep Alquran. 'Aql dalam Alquran terulang sebanyak 49 kali, kecuali satu, semuanya datang dalam bentuk fi'il mudhari', terutama materi yang bersambung dengan wawu jama'ah. Seperti bentuk ta'qilun atau ya'qilun. Kata kerja ta'qilun terulang sebanyak 24 kali dan kata kerja ya'qilun sebanyak 22 kali. Sedangkan, kata kerja 'aqala, na'qilu, dan ya'qilu masing-masing terdapat satu kali.Dari sejumlah ayat Alquran dapat dipahami bahwa, akal memiliki beberapa makna, antara lain daya untuk memahami dan menggambarkan sesuatu, dorongan moral dan daya untuk mengambil pelajaran dan kesimpulan serta hikmah
\end{abstract}

Kata kunci: 'Aqal, 'aqala, ta'qilun.

\section{Pendahuluan}

Manusiamerupakan makhluk terbaik ciptaan Allah sepanjang dunia ini ada. Allah sebagai Pencipta semua makhluk menyatakan secara tegas dalam surat at-Tîn:4 
bahwa Dia telah menciptakan manusia dalam sebaik-baik bentuk. Dilihat dari tujuan penciptaan, kesempurnaan bentuk fisik maka manusia merupakan makhluk terindah yang pernah ada di muka bumi ini. Keindahanini makin sempurna ketika Allah menganugerahi manusia seperangkat alat pendeteksi kebenaran yang dapat digunakan dalam kehidupannya yaitu "akal". ${ }^{1}$ Dengan akal manusia mampu mendesain kehidupan sesuai dengan tuntunan Ilahi. Kekuatan akal menyebabkan manusia dapat membedakan antara yang baik dan yang buruk, benar dan salah, gelap dan terang, menangkap dan meganalisis berbagai peristiwa alam dan lingkungannya.Dalam lintasan sejarah para rasul ditemukan adanya sebagian mereka yang mencari Tuhan dengan menggunakan akal dan nabi Ibrahim pernah melakukan hal tersebut.

Akallah yang membuat manusia berbeda dari hewan, manusialah satu-satunya makhluk yang diberikan kekuatan akal dan karena itulah ia menjadi mulia. Akal adalah suatu daya yang hanya dimiliki manusia dan $\mathrm{k}$ akallah yang memperbedakan manusia dari makhluk lain. Akal adalah tonggak kehidupan manusia dan dasar kelanjutan wujudnya. ${ }^{2}$ Peningkatan daya akal merupakan salah satu dasar pembinaan budi pekerti mulia yang menjadi dasar dan sumber kehidupan dan kebahagiaan bangsa-bangsa. Jika dari manusia dicabut akalnya manusia akan menjadi makhluk lain, mungkin seperti hewan. ${ }^{3}$ Al-aql sering digunakan untuk pengertian pikiran (Reason, Thinking), namun sesungguhya ia memiliki makna yang lebih tinggi dan metafisis, sebagaimana yang digunakan dalam terminologi filsafat Islam, yakni serasi dengan pengertian intellect atau Nous dalam filsafat platonisme. Ia merupakan sebuah potensi, yang terpendam dalam microcosmis manusia, dan yang terwujud dalam bentuk jiwa (spirit). ${ }^{4}$

Islam adalah agama yang menghargai akal, dalam Islamlah agama dan akal buat pertama kalinya menjalin hubung-anpersaudaraan. Di dalam persaudaraan itu, akal menjadi tulang punggung agama yang terkuat dan wahyu sendinya yang terutama. Antara akal dan wahyu tidak bisa ada pertentangan. Mungkin agama membawa sesuatu yang di luar kemampuan manusia memahaminya, tetapi tidak mungkin membawa yang mustahil menurut akal. ${ }^{5}$ Allah memberikan nikmat akal kepada manusia sehingga mengangkat derajatnya kepada tingkat berketuhanan dan kesanggupan untuk mengetahui dan memahami tentang Rabbnya. Ini merupakan nikmat dan kemuliaan tertinggi yang dianugerahkan Allah kepada manusia.

1 Terdapat sejumlah ayat al-Quran yang membahas tentang aql yaitu: 22:46, 7:179, 8:22, 24, $58: 19$, 59:20, 20:124, 127, 17:72, 10:5, 29:43, 14:52, 13:19, 3:190, 191, 6:125, 66:8, 64:11, 29:69, 10:9, 2:269, 8:29. h. 44 .

${ }^{2}$ Harun Nasution, Muhammad Abduh dan Teologi Rasional Mutazilah, (Jakarta: UI-Press, 1987),

${ }^{3}$ Harun Nasution, Muhammad Abduh, h. 44.

${ }^{4}$ Cyril Glasse, Ensiklopedi Islam Ringkas, terj. Ghufron Masadi, (Jakarta: RajaGrafindo Persada, 1996), h. 34.

${ }^{5}$ Harun Nasution, Muhammad Abduh, hal. 46. Baca pula: Muhammad Abduh, Risalah al-Tawhid, (Kairo: Dar al-Manar, 1993), hal. 7. Baca pula: Al-Islam, hal. 8, 23 dan 138. 
Selanjutnya Allah menambahkan fitrah bagi manusia yang sesuai dengan apa yang dibawa para rasul, seperti wahyu dan agama yang disyariatkan Allah bagi manusia. ${ }^{6}$

Banyak pertanyaan yang diajukan kepada nabi saw berkenaan dengan manusia, lalu rasulullah menjawab, "Wahai manusia, segala sesuatu mempunyai wahana (kendaraan atau alat untuk mencapai sesuatu); dan wahana terbaik seseorang adalah akal. Dan yang paling baik petunjuk dan pengetahuannya, diantara kamu, adalah yang paling sempurna akalnya. Rasulullah juga bersabda: Yang paling sempurna akalnya diantara kamu adalah yang paling besar rasa takutnya kepada Allah, dan paling memperhatikan apa yang diperintahkan Allah dan dilarang-Nya, meskipun ia termasuk yang paling sedikit tathawwunya (yakni mengerjakan amal kebaikan lebih daripada yang diwajibkan.)

Berkenaan dengan permasalah di atas, makalah ini akan membahas tentang pandangan Alquran terhadap akal dan diperkaya dengan pembahasan dari sudut pandang filsafat dan theologi.

\section{Pengertian Akal}

Akal berasal dari bahasa Arab dari kata 'aql (عقل) yang berarti akal, fikiran. ${ }^{7}$ Dalam bahasa Indonesia, akal berarti alat berpikir, daya pikir (untuk mengerti, pikiran, ingatan). ${ }^{8}$ Akal juga berarti daya pikir untuk memahami sesuatu, dsb, jalan atau cara melakukansesuatu, daya upaya. ${ }^{9}$ Dalam Lisan al-Arab disebutkan bahwa al-'aql berarti al-bijr yang berarti menahan dan mengekang hawa nafsu. Seterusnya diterangkan bahwa al-'aql mengandung arti kebijaksanaan (al-nuba), lawan dari lemah fikiran (albumq). Al-'aq1 juga mengandung arti qalbu (al-qalb), yang berarti memahami. ${ }^{10}$ Akal adalah daya pikir dalam diri manusia dan salah satu daya jiwa yang mengandung arti berfikir, memahami, dan mengerti. ${ }^{11}$

Kata 'aql sebagai mashdar (kata benda) dari 'aqala tidak didapat dalamAlquran, akan tetapi bentukan dari kata'aqalatersebut dalam bentuk fiil mudhâri (kata kerja) sebanyak 49 kali dan tersebar dalam berbagai surah dalam al-Quran. Kata-kata tersebut misalnya; tăqilûn (al-Baqarah : 44), yaquilûn (al-Furqan : 44 dan Yâsîn : 68), naquilu (alMulk : 10), yăqiluha (al-Ankabût : 43) aqaluhu (al-Baqarah : 2). Disamping kata aqala, al-Quran juga menggunakan kata-kata yang menunjukkan arti berfikir, seperti nazhara (melihat secara abstrak/berfikir), tafakkara (berarti berfikir), Faqiha (memahami), tadabbara (memahami) dan tazdakkara (mengingat). ${ }^{12}$

\footnotetext{
${ }^{6}$ Rabi’ bin Hadi “Umar Al-Madkhaly, Cara Para Nabi Berdakwah, terj. Muhtarudin Abrari, (Tegal : Maktabah Salafy Press, 2002), h. 1.

${ }^{7}$ A. W. Munawwir, Kamus Al-Munawwir Arab-Indonesia, (Surabaya: Pustaka progressif, 1997), h. 957. h. 16

${ }^{8}$ W. J. S. Poerwadarminta, KamusUmum Bahasa Indonesia, edisi III(Jakarta: Balai Pustaka, 2007),

${ }^{9}$ Tim Redaksi, Kamus Besar Bahasa Indonesia edisi III, (Jakarta: Balai Pustaka, 2005), h. 18.

${ }^{10}$ Abuddin Nata, Tafsir Ayat-Ayat Pendidikan, (Jakarta: RajaGrafindo Persada, 2004), h. 136.

${ }^{11}$ Tim Penyusun, Ensiklopedi Islam, Jild. 1, (Jakarta: Ichtiar Baru Van Hoeve, 2005), h. 127.

${ }^{12}$ Tim Penyusun, Ensiklopedi Islam, h. 127.
} 
Menurut Imam al-Ghazali akal memiliki empat pengertian, seharusnya tidak diberikan satu definisi saja untuknya tetapi untuk setiap pengertian ada definisi masing-masing. Adapun pengertian-pengertian tersebut adalah,Pertama, akal adalah suatu sifat yang membedakan manusia dengan binatang, dan merupakan potensi yang dapat menerima dan memahami pengetahuan-pengetahuan yang berdasarkan pemikiran, dan akal mampu menghasilkan produk-produk pemikiran yang canggih. Mengutip pendapat al-Harits bin Asad Al-Muhasibi ketika membuat definisi tentang akal, bahwa "Akal adalah suatu gharizah (naluri asli manusia) yang menyebabkan manusia memiliki potensi untuk mencerap berbagai pengetahuan yang berdasarkan pikiran. Akal ibarat cahaya yang dimasukkan ke dalam hati, sehingga manusia memiliki kesiapan untuk mencerap segala sesuatunya. ${ }^{13}$

Kedua, yang dimaksud dengan akal adalah pengetahuan-pengetahuanyang telah tersimpan dalam diri anak yang mumayyiz. Seperti tentang 'kemungkinan terjadinya segala sesuatu yang mungkin terjadi, dan kemustahilan terjadinya segala sesuatu yang mustahil. Misalnya, pengetahuan bahwa dua lebih banyak daripada satu. Atau bahwa seseorang tidak mungkin berada di dua tempat sekaligus (dalam waktu yang bersamaan). ${ }^{14}$ Ketiga, menurut pengertian ini, yang disebut akal adalah pengetahuanpengetahuan yang diperoleh dari pengalaman-pengalaman tentang berbagai peristiwa dalam perjalanan hidup ini. Orang yang pikirannya tajam karena telah 'diasah' oleh berbagai pengalaman hidup dan memiliki wawasan luas, biasanya disebut 'âqil (orang berakal). Sedangkan orang yang tidak memiliki sifat-sifat seperti itu, biasanya disebut bebal atau dungu (atau tidak berakal). Dengan demikian, hal ini merupakan jenis lain dari pengetahuan-pengetahuan yang juga disebut akal. Keempat, bahwa apabila gharizah seperti itu telah menguat dalam diri manusia, sehingga ia mampu memperhitungkan akibat-akibat yang akan timbul dari segala sesuatunya, dan mampu menundukkan serta mengalahkan hawa nafsu yang mengajak kepada kesenangan yang segera, maka ketika itu ia disebut orang berakal. ${ }^{15}$

Manusia berdasarkan akalnya dapat dibagi kepada empat tingkatan, yaitu, pertama: manusia yang mampu memahami kekuasaan dan kemampuan Allah juga tentang janji dan ancamannya. Kedua, Manusia yang dapat memahami semua kebesaran dan kebenaran Tuhan, tetapi mereka menentangnya demi merenggut kenikmatan dunia.Ketiga, manusia yang mengingkari kebenaran dan tidak bersedia mendekatinya. Mereka menentang kebenaran tersebut, bahkan mengira berada di pihak yang benar padahal mereka berada di ujung kesesatan. Keempat, adalah manusia yang sanggup memahami kebesaran Tuhan sebagai Zat Yang Maha Tunggal dalam

\footnotetext{
${ }^{13}$ Imam al-Ghazali, Ilmu dalam Perspektif Tasawuf al-Ghazali, terj. Muhammad a-Baqir, ( Bandung: karisma, 1996), h. 283.

${ }^{14}$ Imam al-Ghazali, Ilmu dalam Perspektif Tasawuf, h. 285.

${ }^{15}$ Imam al-Ghazali, Ilmu dalam Perspektif Tasawuf, h. 285-286.
} 
mengelola alam raya ini. Golongan ini meyakini bahwa keberhasilan hidup hanya dapat dicapai dengan berpegang teguh pada keimanan terhadap-Nya. ${ }^{16}$

Berbagai pengertian tentang akal sebagaimana tersebut diatas terjadi karena pengaruh dari pemikiran filsafat Yunani, yang banyak menggunakan akal pikiran. Seluruh pengertian akal tersebut adalah menunjukkan adanya potensi yang dimiliki oleh akal itu sendiri, yaitu selain berfungsi sebagai alat untuk mengingat, memahami, mengerti, juga menahan, mengikat dan mengendalikan hawa nafsu. Melalui proses memahami dan mengerti secara mendalam terhadap segala ciptaan Allah sebagaimana dikemukakan pada ayat tersebut di atas, manusia selain akan menemukan berbagai temuan dalam bidang ilmu pengetahuan dan teknologi, juga akan membawa dirinya dekat dengan Allah. Melalui proses menahan, mengikat dan mengendalikan hawa nafsunya membawa manusia selalu berada di jalan yang benar, jauh dari kesesatan dan kebinasaan. ${ }^{17}$

\section{'Aqal dalam Perspektif Alquran : Jenis-jenis dan Fungsinya}

DalamAlquran, kata 'aql (akal) tidak ditemukan dalam bentuk mashdarnya, yang ada hanyalah dalam bentuk kata kerja, masa kini dan masa lampau. Secara bahasa, aql berarti tali pengikat, penghalang. Alquransendiri menggunakannya bagi sesuatu yang mengikat atau menghalangi seseorang terjerumus dalam kesalahan atau dosa. Dari konteks ayat-ayat yang menggunakan kata aql dapat dipahami bahwa ia antara lain mencakup makna, pertama: Daya untuk memahami dan menggambarkan sesuatu, ${ }^{18}$ sebagaimana firman-Nya yang artinya: Demikian itulah perumpamaanperumpamaan yang Kami berikan kepada manusia, tetapi tidak ada yang memahaminya kecuali orang-orang yang alim (berpengetahuan). (Q. S : al-Ankabut : 43). Daya yang dimiliki manusia dalam hal ini berbeda-beda. Hal ini diisyaratakan alQuran antara lain dalam ayat-ayat yang berbicara tentang kejadian langit dan bumi, silih bergantinya malam dan siang dan lain-lain. Ada yang dinyatakan sebagai buktibukti keesaan Allah. Bagi orang-orang yang berakal, (Q. S. al-Baqarah: 164) dan ada juga kata Ulil al-Bâb yang juga dengan makna sama, tetapi mengandung pengertian lebih tajam dari sekedar memiliki pengetahuan. Keanekaragaman akal dalam konteks menarik makna menyimpulkannya terlihat juga dari penggunaan istilah-istilah seperti nazhara, tafakkur, tadabbur, dan sebagainya yang semuanya mengandung makna mengantar kepada pengertian dan kemampuan pemahaman. Kedua, Bermakna dorongan moral, ${ }^{19}$ sebagaimana firman-Nya yang artinya : ... dan janganlah kamu mendekati perbuatan-perbuatan keji, baik yang nampak atau tersembunyi dan jangan kamu membunuh jiwa yang diharamkan Allah kecuali dengan sebab yang benar.

16 Nash Hamid Abu Zaid, Menalar Firman Tuhan, Wacana Majaz dalam al-Quran Menurut Mutazilah, terj. Abdurrahman Kasdi dan Hamka Hasan, (Bandung: Mizan, 2003), h. 81.

${ }^{17}$ Abuddin Nata, Tafsir, h. 136.

${ }^{18}$ M. Quraish Shihab, Wawasan al-Quran, (Bandung: Mizan, 2005), h. 294.

${ }^{19}$ M. Quraish Shihab, Wawasan, h. 294. 
Demikian itu diwasiatkan Tuhan kepadamu semoga kamu memiliki dorongan moral untuk meninggalkannya. (Q. S. al-Anam: 151).

Ketiga, Daya untuk mengambil pelajaran dan kesimpulan serta hikmah. Untuk maksud ini biasanya digunakan kata rusyd. Daya ini menggabungkan kedua daya di atas, sehingga ia mengandung daya memahami, daya menganalisis dan menyimpulkan serta dorongan moral yang disertai dengan kematangan berfikir. Seseorang yang yang memiliki dorongan moral, boleh jadi tidak memiliki daya nalar yang kuat dan boleh jadi pula seseorang yang memiliki daya pikir yang kuat, tidak memiliki dorongan moral, tetapi seseorang yang memiliki rusyd, maka dia telah menggabungkan kedua keistimewaan tersebut. ${ }^{20}$ Dari sini dapat dimengerti mengapa penghuni neraka di hari kemudian berkata : "Seandainya kami mendengar dan berakal maka pasti Kami tidak termasuk penghuni neraka.” (Q. S: al-Mulk:10).

Kata al-`aql dalam Alquran juga bermakna intelellect. Dalam penggunaannya kata al-`aql mengandung pengertian kemampuan berpikir atau menggunakan nalar. Kata ini telah terserap ke dalam bahasa Indonesia yaitu kata akal. Dalam perkembangannya orang yang memiliki kemampuan berpikir dan nalar sangat tinggi, serta menguasasi suatu pengetahuan tertentu secara sistematis lazim disebut pakar. Seorang pakar belum tentu seorang sarjana. Kata intelektual yang artinya sebanding dengan ulu al-bâb adalah orang yang memiliki dan menggunakan daya intelek (pikiran untuk bekerja atau melakukan kegiatannya. Biasanya intelektual adalah orangyang berpendidikan akademis. ${ }^{21}$ Secara harfiah, intelektual adalah orang yang memiliki intelek yang kuat atau intelegensi yang tinggi. Intelegensi adalah kemampuan kognitif atau kemampuan memahami yang dimiliki seseorang untuk berfikir dan bertindak rasional atau berdasar nalar. Kemampuan tersebut bisa diperoleh karena keturunan atau bakat yang ada pada seseorang dari faktor biologisnya, tetapi bisa pula diperoleh sebagai hasil pengalaman lingkungan dan sosialisasi berdasarkan penerimaan norma-norma yang baik-buruk dan benar-salah menurut masyarakat. $^{22}$

Tinggginya kedudukan akal bagi manusia, menyebabkan pembahasan tentangnya menjadi demikian komplit, rumit dan menarik. Tidak mengherankan jika kajian tentang akal menjadi trending topik dalam banyak bidang keilmuan, seperti bidang Pendidikan, Ushul Fiqh, Dakwah, Theologi dan Filsafat. Pembahasan-pembahasan tersebut umumnya membahas tentang fungsi akal dalam kehidupan manusia dan kaitannya dengan masingmasing bidang ilmu.Dalam kajian Theologi/Ilmu Kalam, akal mendapatkan posisi tersendiri sehingga menjadi salah satu kajian menarik terutama tentang fungsi dan kedudukannya. Bagi pengikut aliran Mutazilah dan Syiah yang terkenal rasionalis, mereka memberikan posisi yang tinggi terhadap akal, sementara bagi kaum Asyariyyah hanya memberikan porsi yang kecil tehadap akal.

\footnotetext{
${ }^{20}$ M. Quraish Shihab, Wawasan, h. 295.

${ }^{21}$ M. Dawam Rahardjo, Ensiklopedi al-Quran, Tafsir Sosial Berdasarkan Konsep-Konsep Kunci, (Jakarta: Paramadina, 2002), h. 558.

${ }^{22}$ M. Dawam Rahardjo, Ensiklopedi al-Quran, h. 558.
} 
Akal dalam pengertian Islam adalah daya berfikir yang terdapat dalam jiwa manusia, yaitu daya sebagai yang digambarkan Alquran, memperoleh pengetahuan dengan memperhatikan alam sekitarnya. Akal dalam pengertian ini yang dikontraskan dalam Islam dengan wahyu yang membawa pengetahuan dari luar diri manusia yaitu Tuhan. ${ }^{23}$

Muhammad Abduh, memberikan kedudukan yang tinggi terhadap akal, sehingga akal dalam pendapatnya memiliki kemampuan untuk:

1. Mengetahui Tuhan dan sifat-sifat-Nya

2. Mengetahui adanya hidup di akhirat

3. Mengetahui bahwa kebahagiaan jiwa di akhirat bergantung pada mengenal Tuhan dan berbuat baik, sedangkan kesengsaraannya bergantung pada tidak mengenal Tuhan dan pada perbuatan jahat.

4. Mengetahui wajibnya manusia mengenal Tuhan.

5. Mengetahui wajibnya manusia berbuat baik dan wajibnya ia menjauhi perbuatan jahat untuk kebahagiaannya di akhirat.

6. Membuat hukum-hukum mengenai kewajiban tersebut. ${ }^{24}$

Menurut Ibn Bajjah, manusia dapat mencapai puncak marifah dengan akal semata, bukan dengan jalan sufi melalui al-qalb atau al-zauq. Manusia menurutnya setelah bersih dari sifat kerendahan dan keburukan masyarakat akan dapat bersatu dengan Akal Aktif dan ketika itulah ia akan memperoleh puncak marifah karena limpahan dari Allah. ${ }^{25}$ Para teolog juga membahas kedudukan akal sebagai daya berfikir yang terdapat dalam diri manusia. Pembahasan mereka berkisar sekitar apakah akal mampu mengetahui tuhan, berterima kasih kepada Tuhan, mengetahui baik buruk, serta kewajiban melakukan yang baik dan menjauhi yang buruk. Dalam keempat masalah ini terdapat pembahasan yang panjang dan membawa implikasi yang jauh dalam posisi akal menurut pandangan masing-masing aliran. ${ }^{26}$

Segala pengetahuan dapat diperoleh dengan perantaraan akal, dan kewajibankewajiban dapat diketahui dengan pemikiran yang mendalam.Dengan demikian, berterima kasih kepada Tuhan sebelum turunnya wahyu adalah wajib. Baik dan jahat wajib diketahui melalui akal, demikian pula mengerjakan yang baik dan menjauhi yang jahat adalah wajib pula. ${ }^{27}$ Bagi kaum mutazilah yang dipandang sebagai rasionalis, berpendapat bahwa akal memiliki kemampuan untuk mengetahui Tuhan, kewajiban mengetahui Tuhan, mengetahui baik dan jahat serta kewajiban mengerjakan yang baik dan menjauhi yang jahat. Berbeda dengan mutazilah, bagi galongan asyariyyah, bahwa akal tidak memiliki kemampuan untuk mengetahui soal baik dan buruk, demikian pula halnya dengan kewajiban-kewajiban manusia terhdap Tuhan tidak dapat diketahui melalui akal, melainkan harus ditentukan oleh wahyu.

${ }^{23}$ Harun Nasution, Akal dan Wahyu dalam Islam, (Jakarta : UI-Press, 1986), h.13.

${ }^{24}$ Harun Nasution, Muhammad Abduh, h. 53.

${ }^{25}$ Sirajuddin Zar, Filsafat Islam, h. 196.

${ }^{26}$ Tim Penyusun, Ensiklopedi Islam, h. 127.

${ }^{27}$ Harun Nasution, Teologi Islam: Aliran-Aliran Sejarah Analisa Perbandingan, (Jakarta: UI-Press, 1986), h. 80. 
Akal memiliki daya yang kuat, karena akal dapat mengetahui adanya Tuhan dan kehidupan di sebalik hidup dunia. Akal dapat sampai kepada pengetahuan yang lebih tinggi. Manusia melalui akalnya dapat mengetahui bahwa berterima kasih kepada Tuhan adalah wajib, bahwa kebajikan adalah dasar kebahagiaan dan kejahatan dasar kesengsaraan di akhirat. ${ }^{28} \mathrm{Nashr}$ Hamid, mengutip pendapat al-Harits al-Muhasibi, seorang tokohmu tazilah,menyatakanfungsi akal adalah untuk mendapatkan pengetahuan, bahwa ilmu pengetahuan dapat diperoleh melalui tiga tahapan, yaitu, tahapanpertama, melalui naluri fithriah atau bawaan sejak lahir yang telah diberikan Allah kepada sekalian banyak makhluk-Nya dan manusia tidak memiliki celah untuk memperolehnya baik melalui penglihatan maupun melalui pengindraan, tetapi Allah mengajarkan pengetahuan ini melalui akal. Tahapan Kedua, tahapan teorisasi dan analisis. Dalam hal ini, maka akal berfungsi sebagai sarana untuk mengkaji data atau bahan bukti untuk memperoleh pengetahuan, maka status akal adalah pengelola data. Ketiga, disini posisi akal adalah sebagai pihak yang mencari pengetahuan berdasarkan data yang ada. Tahapan Ketiga, adalah tahapan yang muncul setelah tahapan teorisasi atau pembuktian. Tahapan ini disebut tahapan pengetahuan atau tahapan kesempurnaan akal.Padatataran ini manusia memiliki beragam tingkatan pemaham-an sesuai dengan kadar kemampuan melakukan pembuktian. ${ }^{29}$

Akal memahami prinsip dan motivasi prilaku, sehingga tindakan dan perbuatan timbul secara alami dan penuh kepuasan. Metode akal adalah metode manusiawi yang bertujuan untuk membela hak-hak manusia, akal, kebebasan, dan musyawarah. Metode akal merupakan faktor ideologis di atas mana peradaban berdiri. akal adalah pembentuk peradaban, dan tingkat kemajuan suatu peradaban diukur dengan tingkat rasionalismenya. Akallah yang mampu menyerap segala macam benturan peradaban dan semua teori yangbertentangan, kemudian kembali membangun-nyadalm teori rasional umum. Metode akal memiliki kemam-puan yang tinggi untuk menyerap semua peradaban yang ada. Metode akal mengunggulkan yang baru ketimbang yang lama, lebih mementingkan masa depan daripada masa lalu, serta berdiri atas dasar keberanian rasional dan percaya diri. Pada akhirnya metode akal menimbulkan keterbukaan terhadap orang lain karena adanya kemampuan untuk berdialog, sehingga terhindar dari fanatisme. Jadi, dalil akal merupakan jalan untuk mengukuhkan kebenaran. ${ }^{30}$

Sementara di kalangan para filosof, mereka juga memandang akal dari sudut pandang filsafat, sebagai contoh, al-Farabi, yang menyatakan bahwa ada tiga jenis akal, yaitu Allah sebagai 'aqal, akal-akal dalam filsafat emanasi dan akal yang terdapat pada diri manusia.Akal jenis ketiga adalah akal sebagai daya berfikir yang terdapat dalam jiwa manusia. akal ini juga tidak berfisik tapi bertempat pada materi. ${ }^{31}$ Akal jenis ini

${ }^{28}$ Harun Nasution, Muhammad Abduh, h. 34.

${ }^{29}$ Nash Hamid Abu Zaid, Menalar Firman Tuhan, h. 80-81.

${ }^{30}$ Hassan Hanafi, Dari Aqidah ke Revolusi Sikap Kita Terhadap Tradisi Lama, terj. Asep Usman Ismail dkk, (Jakarta: Paramadina, 2003), h. 188.

${ }^{31}$ Sirajuddin Zar, Filsafat Islam, Filosof dan Filsafatnya (Jakarta: RajaGrafindo Persada, 2007), h. 88. 
bertingkat-tingkat yang terdiri dari akal Potensial, akal Aktual dan akal Mustafad, akal yang disebut terakhir ini yang dimiliki para filosof yang menangkap cahaya yang dipancarkan Allah ke alam materi melalui akal Kesepuluh (Akal Faal). ${ }^{32}$

Bagi al-Farabi, bila akal teoritis telah ada secara aktual pada jiwa seseorang, maka berarti dia sudah memiliki kesempurnaan tingkat pertama sebagai manusia. Manusia pada umumnya dapat mencapai kesempurnaan tingkat pertama ini. Kesempurnaan tingkat kedua atau tertinggi tercapai bila jiwanya memperoleh akal mustafad. Mayoritas manusia tidak berhasil mengaktualkan akal mustafad pada jiwa manusia mereka. Siapa yang berharap atau berkeinginan mengaktualkan akal mustafad pada jiwanya, haruslah lebih dahulu berupaya keras menjalani hidup zuhud, (menjauhkan diri dari mengejar kesenangan materi/fisik), dan berupaya keras menguasasi sebanyak mungkin bentuk-bentuk atau artiarti yang dilepaskan dari materi/ide-ide yang bersifat keilmuan. Bila ini telah dicapai maka berarti jiwanya sudah berada dalam taraf siap menerima bentuk-bentuk murni ideide yang tidak bersifat keilmuan) atau akal mustafad yang dilimpahkan oleh akal aktif. Mereka yang memperoleh akal mustafad disebut dengan filsuf. ${ }^{33}$

Aristoteles dalam pembahasannya tidak menjelaskan sama sekali tentang kesatuan dan individualitas kepribadian manusia. Dari sinilah kemudia para filosof muslim lantas memformulasikan seluruh teorinya tersebut dan memasukkan banyak tambahan serta perubahan yang tidak terdapat dalam buku Aristoteles maupun dalam buku-buku komentarnya, seperti pembahasan tentang : Pertama, al-'aqlul-mustafad yaitu : Akal yang diperoleh atau akal tetap, yaitu akal yang dimiliki melalui pemahaman terhadap bentukbentuk universal, konsep-konsep tertinggi dan berbagai macam pengetahuan yang melalui pemilikan itu ia semakin banyak ikut ambil bagian dalam akal pendorong, kadang-kadang disebut juga al-'aqlul bil-malakah.Kedua, al-'aqlun-nazari yaitu nalar atau akal teoretik yang memungkinkan kita membentuk konsep-konsep universal, memahami berbagai macam makna dan saling hubungan di antara bebagai hal, melibatkan diri dalam diskusi awgumentatif dan memiliki pemikiran abstrak secara umum. Lihat juga al-quwwatul'aqliyyah. Ketiga, Al-'aqlul-hayalani merupakan akal material, atau disebut al-'aqlu bilquwwah, yaitu akal potensial. Ia adalah akal manusia dalam bentuknya yang belum diaktifkan, sekedar kemampuan terpendam untuk memahami hal-hal yang universal dan kebenaran-kebenaran abadi yang ada dalam akal aktif atau akal pendorong. ${ }^{34}$ Akal adalah karunia Allah yang terbesar untuk manusia. Dengan akal manusia dapat memperoleh manfaat sebanyak-banyaknya bahkan dapat memperoleh pengetahuan tentang Allah. Oleh sebab itu, manusia tidak boleh menyia-nyiakan dan mengekangnya, tetapi harus memberikan kebebasan padanya dan harus merujuknya dalam segala hal. ${ }^{35}$ Menurut aliran al-Asyariyyah, akal adalah insting (gharîzah) yang dikaruniakan Allah kepada manusia.

\footnotetext{
${ }^{32}$ Harun Nasution, Akal dan Wahyu Dalam Islam, (Jakarta: Universitas Indonesia, 1983), h. 11.

${ }^{33}$ Abdul Aziz Dahlan dkk, Ensiklopedi Tematis Dunia Islam, Pemikiran dan Peradaban, (Jakarta:Ichtiar Baru Van Hoeve, 2002), h. 189.

${ }^{34}$ M. Said Syaikh, Kamus Filsafat Islam, terj. Machnun Husein, (Jakarta : Rajawali, 1991), h. 93.

${ }^{35}$ Sirajuddin Zar, Filsafat Islam , Filosof dan Filsafatnya, (Jakarta: RajaGrafindo Persada, 2007), h. 121.
} 
Dengan akal tersebut, manusia dewasa sanggup menyuguhkan argumentasi. Lebih lanjut disebutkan bahwa akal adala naluri (gharîzah) yang melahirkan manusia, memberinya pengetahuan melalui sebab-sebab yang dapat membantunya mengenali hal-hal yang dapat dipersepsi oleh akal. ${ }^{36}$

Folosof lainnya al-Razi mengatakan bahwa Akal seseorang adalah kemampuan yang dimilikinya untuk memahami dan menangkap yang ada dibalik kenyataan. Akal dimungkinkan untuk mengadakan perenungan dan pencarian kebenaran terhadap fenomena dan gejala yang ada di alam semesta. Akal adalah alat penalaran dan perolehan pengetahuan. ${ }^{37}$

Al-Razi, merumuskan kategori kemampuan akal kepada beberapa tingkat, yaitu

1. Al-Uqul al-Hayyulaniyyah, material intelect, atau akal material. Akal semacam ini belum terisi oleh pengalaman dan pengetahuan. Dia punya kemampuan untuk memperoleh pengetahuan dan pengalaman. Akal ini baru dimiliki oleh anak-anak dan ada pada tingkat yang paling bawah.

2. Al-Uqul bi al-Malakah, faculty intelect atau akal dalam kapasitas. Dia bukan hanya sebagai akal material, tetapi telah mempunyai kapasitas dan kemampuan untuk menangkap pengalaman dan pengetahuan awal (al-ulum al-badihiyyah). Melalui pengetahuan awal, akal mencoba menyusunnya dalam suatu bentuk rumusan. Rumusan yang disusun berbeda diantara setiap orang. Perbedaannya adalah didasarkan kepada sedikit pengalaman atau pengetahuan dasar, disamping banyaknya kapasitas penggunaan pengalaman dan pengetahuan awal dalam membentuk rumusan-rumusan pengetahuan yang terorganisasi.

3. Al-Uqul bi al-fi'l, akal dalam aktualitas. Akal itu bukan saja material dan kapasitas, namun dia telah mempunyai kemampuan dalam menangkap pengetahuan (al-ulum al-kasbiyyah)', dan juga telah mempunyai kemampuan untuk mereproduksi pengetahuan yang diperoleh dengan tidak menggunakan ekstra perhatian dan kemampuan.

4. Al-'Aql al-Mustafad, acquired intelect. Akal ini mampu mengungkap pengetahuan tanpa melalui tangkapan inderawi dan dapat mengaktualisasikan pengetahuan secara jelas dan tepat. Inilah derajat akal tertinggi dan dikatakan sederajat dengan malaikat. ${ }^{38}$

Berdasarkan analisis ini dapat dikatakan bahwa akal dalam rumusan al-Razi mempunyai peran yang besar untuk memperoleh pengetahuan, sehingga pengetahuan seseorang atas dasar pertimbangan kemampuan penalaran dikategorikan dalam empat kategori, yaitu : pengetahuan yang berkaitan dengan ketuhanan, dimana pengetahuan ini berada di posisi tertinggi; pengetahuan yang diperoleh dengan meniru, taklid dan merasa cukup dengan yang diperoleh. Dalam kotegori ini, penalaran akal digunakan untuk membenarkan pengetahuan yang telah ada dibenaknya; disisi lain ada pula bentuk

\footnotetext{
${ }^{36}$ Nash Hamid Abu Zaid, Menalar Firman Tuhan, h. 80.

${ }^{37}$ Teuku Safir Iskandar, Falsafah Kalam, Kajian Teodesi Filsafat Teologis Fakhr al-Din al-Razi, (Lhokseumawe-Nanggroe Aceh Darussalam : Nadiya Foudation, 2003), h. 69.

${ }^{38}$ Teuku Safir Iskandar, Falsafah Kalam, h. 69-70.
} 
pengetahuan yang semata-mata bersandarkan pada kepercayaan, ukuran benar atau salah; dan yang terakhir adalah sama sekali tidak mempunyai pengetahuan. ${ }^{39}$

Pentingnya kedudukan akal dalam pemikiran al-Razi membuat perbedaan seseorang terlihat pada tingkatan penguasaan pengetahuan dan ketajaman penalaran. Seseorang dalam kategori pertama dan akal keempat adalah yang tertinggi kedudukan dan kuat penalaran intelektualnya. ${ }^{40}$ Kehadiran intellect di dalam diri manusia membuatnya berbeda dengan mahkluk binatang, sekalipun binatang terlibat dengan alam sekitarnya, namun ia tidak terkait erat sehingga binatang tidak menduduki posisi sebagai center, melainkan manusia. Dengan cara demikian Adam menjadi tahu terhadap nama-nama dari objek alam sedangkan malaikat tidak mengetahuinya, dengan alasan yang hampir sama di atas, karena malaikat tidak terkait erat dengan lingkungan alam dan tidak pula menerima sinaran intellect ketuhanan di dalam dirinya. Memang, pada satu sisi, malaikat kedudukannya lebih tinggi dari pada Adam lantaran mereka lebih tidak terbatas dari pada Adam, namun malaikat ternyata bersujud menghormat kepada Adam disebabkan karena lebih tingginya kedudukan Adam sebagai wakil Allah di muka bumi (khalifah Allah fi alArd) Baca. Lima Prinsip Kehidupan Ketuhanan. ${ }^{41}$

Dengan akal itulah hamba-hamba Allah mengenal-Nya. Mereka menyaksikan wujud-Nya dengan akal itu, yang mereka kenal dengan akal mereka juga, dan dengannya mereka mengetahui apa yang bermanfaat dan mengetahui apa yang membahayakan mereka. Jadi siapa yang mengetahui dan dapat membedakan apa yang bermanfaat dan apa yang berbahaya baginya dalam urusan kehidupan dunianya, maka dia telah mengetahui bahwa Allah telah menganugerahinya dengan akal yang dicabutnya dari orang gila atau yang tersesat dan juga dari sekalian banyak orang picik yang hanya sedikit memiliki akal. Ada yang berpendapat bahwa akal terdiri dari dua macam. Akal yang merupakan anugerah Allah dan akal yang dapat diperoleh dan dikembangkan oleh manusia melalui penalaran, pendidikan, dan pengalaman hidup. ${ }^{42}$

Orangyang mampu menggunakan akalnya secara maksimal dalam kehidupan disebut oleh al-Qur'an dengan ulul al-bâb. Ulul al-bâb merupakan satu istilah yang diberikan Allah kepada mereka yang mampu menangkap isyarat-isyarat Allah melalui akal dan bimbingan wahyu dalam semua dimensi kehidupannya. Karena istilah ini diberikan oleh al-Quran maka tidak ada satu terjemahan pun yang paling tepat kecuali terminology ulul albâb itu sendiri. Namun sering juga ia diartikan dengan orang yang mempunyai akal. Orang yang memiliki akal disini adalah yang mendapat kehormatan dari Tuhan, berupa tantangan Tuhan untuk mengetahui rahasia-rahasia langit dan bumi. ${ }^{43}$

Dalam pemahaman Profesor Izutzu, sebagaimana dikutip Harun Nasution, bahwaa 'aql di zaman jahiliyah dipakai dalam arti kecerdasan praktis (practical intellegence) yang

${ }^{39}$ Teuku Safir Iskandar, Falsafah Kalam, h. 69-70.

${ }^{40}$ Teuku Safir Iskandar, Falsafah Kalam, h. 69-70.

${ }^{41}$ Cyril Glasse, Ensiklopedi Islam Ringkas, h. 34.

${ }^{42}$ M. Quraish Shihab, Logika Agama : Kedudukan Wahyu \& Batas-Batas Akal dalam Islam, (Jakarta: Lentera Hati, 2005), h. 87.

${ }^{43}$ Muhammad Muhyiddin, Cara Islami Melejitkan Citra Diri, (Jakarta : Lentera, 2003), h. 123. 
dalam istilah psikologi modern disebut kecakapan memecahkan masalah (problem solving capacity). Orang berakal menurut pendapatnya adalah orang yang mempunyai kecakapan untuk menyelesaikan masalah, setiap kali ia dihadapkan dengan problema dan selanjutnya dapat melepaskan diri dari bahaya yang dihadapi. Kebijaksanaan praktis serupa ini dihargai oleh orang Arab zaman jahiliyah. Orang yang berakal akan memiliki kesanggupan untuk mengelola dirinya dengan baik, agar ia selalu terpelihara dari mengikuti hawa nafsu, berbuat sesuatu yang dapat memecahkan dan memberikan kemudahan bagi orang lain, dan sekaligus orang yang tajam perasaan batinya untuk merasakan sesuatu di balik masalah yang dipikirannya. Dalam kaitan inilah, maka di dalam al-Qur'an, sebagaimana dijelaskan pada ayat 45 surat al-Hajj, bahwa pengertian, pemahaman dan pemikiran dilakukan melalui kalbu yang berpusat di dada. ${ }^{44}$

Akal terdiri dari atas unsur rasio dan hati/rasa. Setelah manusia memikirkan/merasio tanda-tanda kekuasaan Allah yang terbentang di alam atau tertulis dalam kitab-Nya, maka tidak akan mengakui adanya Allah kalau hatinya tidak berfungsi, sebab buta, tidak yakin dan kotor. Begitu juga, sesuatu yang masuk akal belum tentu dapat dirasionalkan, sebab berfungsinya kemampuan rasio manusia sangat terbatas, hatinya buta dan menyebabkan tidak yakin. Sementara sesuatu yang rasional akan dapat diterima akal, karena dalam akal manusia terdapat unsur hati/rasa percaya. Akal manusia akan semakin berfungsi dengan baik, manakala unsur rasa atau hatinya baik, suci dan senantiasa beriman. ${ }^{45}$

\section{Penutup}

Dari uraian di atas dapat disimpulkan bahwa akal merupakan salah satu potensi yang dianugerahkan Allah kepada manusia yang digunakan sebagai daya untuk berfikir. Akal merupakan salah satu keistimewaan yang dimiliki oleh manusia yang tidak dimiliki oleh makhluk lain sehingga menjadikannya pantas menjadi khalifah.

Dari sejumlah ayat Alquran dapat dipahami bahwa, akal memiliki beberapa makna, antara lain daya untuk memahami dan menggambarkan sesuatu, dorongan moral dan daya untuk mengambil pelajaran dan kesimpulan serta hikmah. Sementara dari dari sudut pandang filsafat, terdapat beberapa klasifikasi terhadap akal,yaitu : Al-Uqul alHayyulaniyyah, atau akal material, Al-Uqul bi al-Malakah, yaitu akal dalam kapasitas, AlUqul bi al-fi'l yaitu akal dalam aktualitas dan Al-'Aql al-Mustafad atau akal perolehan.

\footnotetext{
${ }^{44}$ Abuddin Nata, Tafsir, hal. 137.

${ }^{45}$ Choiruddin Hadhiri, Klasifikasi Kandungan al-Quran, Jld. I, (Jakarta: Gema Insani, 2005), hal.
} $62-63$. 


\section{DAFTAR PUSTAKA}

A. W. Munawwir, Kamus Al-Munawwir Arab-Indonesia, Surabaya: Pustaka progressif, 1997.

Abdul Aziz Dahlan dkk, Ensiklopedi Tematis Dunia Islam, Pemikiran dan Peradaban, Jakarta:Ichtiar Baru Van Hoeve, 2002.

Abuddin Nata, Tafsir Ayat-Ayat Pendidikan, Jakarta: RajaGrafindo Persada, 2004.

Choiruddin Hadhiri, Klasifikasi Kandungan al-Quran, Jld. I, Jakarta: Gema Insani, 2005.

Cyril Glasse, Ensiklopedi Islam Ringkas, terj. Ghufron Masadi, Jakarta: RajaGrafindo Persada, 1996.

Harun Nasution, Akal dan Wahyu dalam Islam, Jakarta: Universitas Indonesia, 1983. Press, 1987.

Hassan Hanafi, Dari Aqidah ke Revolusi Sikap Kita Terhadap tradisi Lama, terj. Asep usman Ismail dkk, Jakarta: Paramadina, 2003.

Imam al-Ghazali, Ilmu dalam Perspektif Tasawuf al-Ghazali, terj. Muhammad a-Baqir, Bandung: karisma, 1996.

M. Dawam Rahardjo, Ensiklopedi al-Quran, Tafsir Sosial Berdasarkan Konsep-Konsep Kunci, Jakarta: Paramadina, 2002.

M. Quraish Shihab, Logika Agama : Kedudukan Wahyu \& Batas-Batas Akal dalam Islam, Jakarta: Lentera Hati, 2005. , Wawasan Al-Qur`an, Bandung: Mizan, 2005.

M. Said Syaikh, Kamus Filsafat Islam, terj. Machnun Husein, Jakarta : Rajawali, 1991 Muhammad Abduh, Risalah al-Tawhid, Kairo: Dar al-Manar, 1993.

Nash Hamid Abu Zaid, Menalar Firman Tuhan, Wacana Majaz dalam al-Qur'an Menurut Mu`tazilah, terj. Abdurrahman Kasdi dan Hamka Hasan, Bandung: Mizan, 2003.

Rabi bin Hadi Umar Al-Madkhaly, Cara Para Nabi Berdakwah, terj. Muhtarudin Abrari, Tegal: Maktabah Salafy Press, 2002.

Sirajuddin Zar, Filsafat Islam, Filosof dan Filsafatnya, Jakarta: RajaGrafindo Persada, 2007.

Teuku Safir Iskandar, Falsafah Kalam, Kajian Teodesi Filsafat Teologis Fakhr al-Din al-Razi, Lhokseumawe-Nanggroe Aceh Darussalam : Nadiya Foudation, 2003.

Tim Penyusun, Ensiklopedi Islam, Jild. 1, Jakarta: Ichtiar Baru Van Hoeve, 2005.

Tim Redaksi, Kamus Besar Bahasa Indonesia, edisi III, Jakarta: Balai Pustaka, 2005.

W. J. S. Poerwadarminta, KamusUmum Bahasa Indonesia, edisi III, Jakarta: Balai Pustaka, 2007. 